\title{
Analyzing Concept and Functions of Fairness in the Islamic Economic System and Presenting Some Teachings for Existing Economic Systems*
}

\author{
İslam Ekonomik Sisteminde Hakkaniyet Konseptinin ve \\ Hakkaniyetin Işlevlerinin Incelenmesi ve Mevcut Ekonomik \\ Sistemler için Bazı Öğütler
}

\author{
Mohammad Abdolhosseinzadeh (1) \\ Seyed Ali Mohamad Najafi Farashah (2) \\ (1), (2) Faculty of Management and Accounting, Allameh Tabataba'i University, Iran \\ (1)m.abdolhosseinzadeh@atu.ac.ir, (2)sa.najafi@atu.ac.ir
}

\begin{abstract}
One of the most important concepts and indicators in the Islamic Economic System is fairness. The present study intends to examine this important rule in the economics literature and Islamic texts in order to analyze its various dimensions and aspects. In the present study, the functions of fairness are described in four field in the legal system of economy, international trade, transactions and banking. The added value of the present research is that fairness is one of the policy instruments for evaluating and monitoring the Economic System performance. Finally, some teachings of this important rule are presented to improve domestic and international Economic Systems. Institutionalizing and realizing fairness in the Economic System leads to the justice of the information system, reduce the control cost, realize the fair system of information flow in order to secure the right, fairness in determining the production profit or the added value of commodity, resolve the problem of transparency and symmetry of information in financial markets, the social balance in economic issues, improve the accountability in Economic System.
\end{abstract}

Keywords: Economic System, Justice, Islamic economics, International Economy

Öz: Islam Ekonomik Sistemindeki en önemli yaklaşım ve ögelerden biri hakkaniyettir. Elinizdeki bu çalışma ekonomi literatürü ve Islami metinlerde geçen bu önemli kaideyi farklı boyutları ile analiz etmeyi amaçlamaktadır. Bu çalışmada hakkaniyetin işlevleri ekonomi, uluslararası ticaret, alış veriş işlemleri ve bankacılık alanlarını tanımlayan hukuki çerçeve içinde dört ana alanda

ORC-ID: M. Abdolhosseinzadeh 0000-0002-5884-9985 S. A. M. N. Farashah 0000-0003-2937-1078 "This article is a review of the paper presented at the "5th International Ibn Khaldun Symposium" organized on 27-28 April 2019 in Istanbul. 
tanımlanmıştır. Çalışmanın sonucunda hakkaniyet konseptinin ekonomik sistemin performansının değerlendirilmesinde ve izlenmesinde önemli bir politika aracı olduğu tespiti yapılmıştır. Sonuç olarak bu önemli kaidenin ışığında yerel ve uluslararası ekonomik sistemi gelişsirecek bazı noktalar sunulmuştur. Ekonomik sistemde hakkaniyetin kurumsallaşması ve gerçekleştirilmesi bilgi sistemlerinde adalete, kontrol maliyetinin azaltılmasına ve hakların korunması adına adil bir bilgi akışının kurgulanmasına, üretim karlarının veya ürünün katma değerinin belirlenmesi konusunda hakkaniyete, finansal piyasalarda bilginin simetrik ve şeffaf olarak dağılmasına, ekonomik alanda Sosyal dengeye ve ekonomik sistemde hesap verebilirliğin gelişmesine katkı sunacaktır.

Anahtar Kelimeler: Ekonomik Sistem, Adalet, Islam Ekonomisi, Iktisat, Uluslararası Ekonomi

\section{Introduction and the Problem Statement}

Different Economic Systems are based on schools and the epistemological basis and ontology of the self. This makes the principles, concepts and tools to be different in Economic Systems. Economic System based on Islamic school is one of the well-known Economic Systems in the world. The Islamic Economic System has some components and elements specific to itself, as well as some other components in the Islamic Economic System which is common to other Economic Systems. The common features of the Islamic Economic System with other Economic Systems do not mean full compliance with other Economic Systems. One of the components of the Islamic Economic System is the concept of fairness which is more or less present in other Economic Systems.

In the Islamic school and Economic System, at first glance, observing justice and fairness in social and economic interactions is one of the moral necessities. But the concept of fairness in the Economic System is not just a moral necessity, but sometimes it also takes legal and juridical aspects. One of the concepts that has a meaning close to fairness in terms of semantics and application is the concept of justice.

In the context of Islamic studies, both in the field of politics, jurisprudence and law, as well as economics, there has been paid little attention to the recognition of the fairness concept and its relation with justice. Providing a clear definition of fairness against justice is not just a theoretical debate. This debate can be the source of governmental policy-making. If fairness is considered to be as justice or necessary for justice, the legal system is required to protect it. On the contrary, if fairness is considered as a virtue beyond justice, the most appropriate policy is to promote fairness, create a supportive framework for fairness observance, develop a legal framework for fairness, and create the culture of fair trade (Tavakoli, 2015). 
Regarding the necessity of paying attention to fairness in economic policy, it must be stated that it is vital for each economic planner to pay attention to the principle of fairness for ensuring the welfare of community and reaching important goals such as social satisfaction, social awareness, and policy decisions about variables such as resource distribution, justice, motivation, efficiency, and altruism are important. From this perspective, we can say that a society with egalitarian thinking of fairness requires to plan and build a system of legal and economic ownership of production, distribution and consumption, and a redistributive tax system which is different from a society which has the tendencies and conception of just deserts or commutative justice.

As stated earlier, in this research we try to create a proper understanding of the fairness concept in the Islamic Economic System, and to describe fairness functions in the Economic System from the aspects of transactions, the legal system of the economy, international trade and Islamic banking.

\section{Concept of Fairness}

One of the most important ambiguities in explaining the concept of justice, is the determination of its relation with concepts such as fairness, equality, and freedom.

In the contemporary discourse of applied ethics, the concept of fairness has sometimes been presented as a concept distinct from justice. For example Joseph Eugene Stiglitz, the Nobel laureate of the economy in 2001 in his book "Fair Trade for All" considers the need for fairness in foreign trade as maximizing the profits of the poorest countries through low tariffs on exports of these countries to the developed countries (Stiglitz\& Charlton, 2007). The proposed Stiglitz principle of fairness is similar to John Rawls's approach in the theory of justice as fairness. Rawls in his justice principles considers it essential to benefit the poor people (Rawls, 1958). This ideas has some critics like Robert Nozick who define justice in a completely liberal framework based on the ownership right (Asghari, 2009, p. 267).

In justice theory of John Rawls, fairness has been proposed as one of the justice tools. In his view, justice will be realized when the initial facilities are distributed equitably among the people and the final distribution will not be excluded from the fairness area (Tavakoli, 2009). Justice such as fairness initially was considered as a radical political concept of justice. A fundamental question that Rawls considers, is the way of people working together in a society in spite of their commitment to "inclusive, deeply conflicting, yet rational beliefs" (Rawls, 1971). 
Chris Cock (2009) in an article entitled "Differences in the justice and fairness concept" considers the former as essential and the latter as preferable. In his view, justice is related to something that is ethically necessary and is opposed to something that is ethically preferable. For example, benevolent help is not is not a justice tool, But is something beyond that; it is something that although ethically is good, but we do not have to do it (Cooke, 2009). Another important point is that fairness is not merely an ethical phenomenon; Other than ethics, the factors such as gender, age, income, and field of study affect people's attitude toward fairness (Taylor, 2015).

As stated earlier, one of the important points is the distinction between the concept of justice and fairness. Aristotle about the difference between fairness and justice says: fairness is like justice, but not law-based justice, but it is correcting legal justice. In other words, the fairness nature is a correction of the law, where there is a defect due to the general rule of law. He states that a fair person is one who does not consider the rule too much where the law is to the detriment of another person, but neglects his own right (Ahangari, 2014).

One of the important issues in economic relations and interactions is observing fairness (Taylor, 2015). fairness in Islam is not just a religion but it is a global political system in which has two synonym words as justice and fairness; and its meaning refers to all terms and conditions before judgment (Falcon Y Tella, 2008). To determine the fairness requirements in the Islamic approach, it is necessary to present a specific criteria to determine the fair condition. Determining this criteria is different in each of the meanings of fairness. If we consider fairness as justice, and the justice as just deserts, there is no difference between the requirements of justice and fairness. If we consider fairness as the same meaning as justice or one of its tools, the justice necessity is the same as the observing the rights; and fairness also relate to areas where people are entitled to equal right. In contrary, the situation in two other fairness usages, is different (Tavakoli, 2015).

Some jurisconsults has referred to fairness as granting half of the property to the other party and considering justice. In this definition, justice and fairness are correlated with each other (Rabbani Mousavian and Naimi, 2018). From a perspective, fairness can be divided into two categories as follows:

- Fairness in speech: the man observes the right and tells the truth as he likes to hear the truth from others. Fairness means confessing to the others' words accuracy.

- Fairness in behavior: man observes the right in dealing with others, places himself in their place, and regards their rights and interests as his own (Amanipour, 2010). 
In general, it can be said that the idiomatic meaning of fairness is the same its literal meaning which means giving the equal right. In other words, the person gives the other the same right that he likes and the same benefits that he enjoys, and the divide the losses equally between himself and the other (Amanipour, 2010). The important point in this definition, is that fairness is the giving of rights, and the profits and losses in the transaction and service are the implied meaning of the right.

\section{Concept of the Economic System}

As stated in the previous sections, this paper seeks to investigate the fairness functions in the Economic System. For this purpose, the present section provides some general points regarding the Economic System and its components.

Holesovsky states that there are four main categories of components that form an Economic System: Resources, Participants, Processes and Institutions. He also divides the Economic System participants into three groups. First, institutions that mainly convert input into output. Second, households that on one hand are the ultimate consumer of output, and on the other hand are suppliers of labor and capital. Third, the government that different schools have different definition about its nature (Mirmoezi, 2006). Also, in the current world with the dominion of the information economy, ignoring processes that include information, decisions, implementation and results is inevitable (Mirmoezi, 2015).

There are two types of institutions in an Economic System:

- First, institutions that indicate the type of communication between participants and resources; patterns of consumption, investment, and savings.

- Second, the institutions that represent the type of communication between participants in the system. Such as the pattern of buying and selling, rent, debt, charity and gift which indicate the type of communication between the people, and receiving tax and spending on government expenditures which express the type of communication between the state and the people (Mirmoezi, 2015).

It can also be stated that current relations in the Economic System are mainly in the form of an exchange relationship with interest-earning incentive (renting, renting, and peace); a participation relationship with interest-earning incentive (bailment of a capital, Sharecropping, farm letting, reward, reconciliation and participation); Sacrifice relationship (charity, interest-free money, endowment (wagf)) (Mirmoezi, 2015). 
In the present study some functions of fairness are described in the components and entities of the Economic System in order to determine the functions of fairness in the Economic System in an exemplary manner. For this reason, fairness will be expressed in the legal system of economics, international trade, transactions and banking.

\section{Functions of Fairness}

In this section, the functions of fairness and its components in the Economic System are shortly described. According to the cases in which were expressed in terms of the concept of fairness as well as the Economic System's conceptualization, in this section, we describe the effects of fairness on the Economic System. By reviewing the scientific resources, the functions of fairness in the present study are described in four areas of international trade, the legal system of economics, transactions and banking.

\subsection{Fairness in the Legal System of Economy}

In legal terms, the principle of fairness is used to resolve legal conflicts and its main meaning is equal distribution of disputed property (Asghari, 2009). In legal terms, fairness means equal rights and justice (Oxford Advanced, 2015, p.423). It can be stated that fairness has undergone three important steps in its evolutionary process:

1) The Anglo-Saxon system which is obviously rooted in facts based on factual proceedings;

2) The Roman-Germanic system which is related to normative process;

3) Islamic legal system which is dedicated to the conscientious values process (Falcon Y Tella, 2008, 45).

Hudson states that the fairness principle is one of the components of British legal system (Hudson, 2015). In the United States, the Supreme Court of Justice has begun to exercise fairness in its own vote, since the late nineteenth century (Sheppard, 2009, p. 414). Generally, the fairness principle is considered as a legal norm which is applied in international treaties \& agreements (Blaszczak, Kolber, 2013). Based on the fairness principle, a judge or referee has more freedom of action, authority and flexibility (Belohlavek, 2013) and he can even decide outside the framework of law and in accordance with moral standards and contrary to the law (Herboczková, 2008).

Also, another instance of the fairness principle in the legal Economic System, is to provide the required infrastructure for the fair access of individuals to the information and flow of information in the Economic System. The fairness principle prescribes that 
any information rents should be eliminated from the Economic System, and the flow of information must be transparent in the Economic System (Sekhon, Roy \& Devlin).

\subsection{Fairness in International Trade}

One of the areas of fairness in the Economic System is related to international relations in international trade and economics. What is needed for fairness in commercial exchanges, is contenting with little profit. Fairness can be expressed in two parts in international trade:

1) Fairness by setting preferential tariffs in favor of poor countries

When the price of a commodity increases sharply due to unexpected changes in the market, selling pre-purchase goods at a new price is in contrary to fairness. It may be said that it is fair that inventory stock is sold at a previous price or price between the previous price and the current price. It is clear that when the seller put himself in the position of purchaser, he wants to be given more discounts. Giving discount is a little benefaction. Because, the seller still receives a profit from the buyer; But, he reduces his profit rate according to his circumstances. What is needed for fairness in trade, is observing the weak parties in trade exchanges and trying to profit them. Observance of fairness in trade can be observed in the form of discount at the profit rate, prioritization of business parties, and so on. Equity in foreign trade makes sense in the form of preferential tariffs in favor of poor countries (Tavakoli, 2015). In short, it can be stated that the need for fairness in business is benefaction as much as possible and discount in the transaction. Fairness like tolerance requires that one of the two parties of the transaction do well to the other one and reduce their profits.

2) Fairness in resolving foreign investment disputes

At present, fairness has become a successor in resolving foreign investment disputes in principles of international trade laws; therefore, fairness should be considered as a substitute resource for international trade law. That is, firstly it should refer to other sources of international trade law as a principle and then consider fairness. By examining international documents and foreign investment contracts, fairness in foreign investment disputes is concerned with resolving disputes and settling them by fairness. In short, fairness is one of the general legal principle that acts as a bridge between different legal systems and plays an important role in resolving foreign investment disputes (Ahangari, 2015). 


\subsection{Fairness in Transactions}

Fairness in the Muslim market trading also has many functions. In the following, four important functions of fairness in transactions are summarized.

1) Giving discount to the buyer

In transactions, fairness means ignoring your own right and discounting the buyer. In other words, in transactions and trading, if the seller finds that the buyer does not have the ability to buy and needs this product, fairness prescribes that the seller ignores his or her own profit or principal (Rabbani Mousavian and Na'imi, 2018).

2) Granting a debt repayment deadline by instalments

Another application of fairness in transactions is to grant a debt repayment deadline by instalments. The basic principle of debt is "to pay in cash", but based on the fairness principle and considering the economic circumstances of the debtor, repayment of debts can be made by installments and by the creditor agreement (Rabbani Mousavian and Na'imi, 2018).

3) Ignoring the debtor's essential property if there is a debt

Also, another application of fairness is that if there is a debt to the debtor, the debtor's or the bankrupt's essential property in which the continuation of his life and his family is based on the them, will not be considered in debt payment. While justice requires a debtor to pay his own debt and the creditor can take the debt out of his property (Rabbani Mousavian and Na'imi, 2018).

4) Discount in the amount of damage or debt

Another application of fairness in transactions is that judicial courts under some conditions and by studying the debtor's circumstances can discount up to certain level in payment of damages. This discount can be performed on the amount of debt with the judicial authority's order and the creditor's satisfaction (Rabbani Mousavian and Na'imi, 2018).

\subsection{Fairness in Banking}

Fairness in the banking system will be one of the key instruments for establishing fairness in the Economic System. The money market is intended to carry out exchanges as the main mechanism of the world economy. According to Islamic teachings, the fairness observance is very close to the ethical banking concept in new economic theories. In the following, the most important principles of fairness in banking will be mentioned. 
1) Non-discrimination: To ensure fairness in banking, the first point is to avoid discrimination. This discrimination in the first phase will be defined for different industries. Banking should not only consider the profitable industries to support the implementation of economic policy. The lack of support for small industries is due to the short-term profitability. This discrimination in the second phase will be defined for individuals in the banking system. And in the last phase, the regional balance will be created by the regional non-discrimination in the banking system.

2) Fairness in determining the interest rate: the banking system will lead to the advance of the Economic System and economic prosperity by decreasing the interest rate and reducing its revenues. This economic prosperity in turn will lead to an increase in the banking system's revenue (Sekhon, Roy \& Devlin, 2016).

3) Balanced growth of wealth and assets in society: With observing fairness in banking, Wealth and assets will have a balanced growth within society and even in different economic sectors of society (Mohagheghnia, 2016, p. 102).

4) Look differently to financial claims: Fair Banking will always have an active approach to solving the claims issue. Providing different solutions, and conducting free advisory services for holders of deferred facilities, will be the first action in the fair banking system. On the other hand, it will help in solving the economic problems of society by providing a deadline and a discount to poor people (Mousavian and Meysami, 2016).

5) Culture-building in line with the fulfilment of obligations: Fair banking, in addition to complying with all its obligations as an indicator of compliance with the obligations and commitments in the Economic System, will lead the society to fulfill its obligations in the concluded contracts by providing the necessary incentives. Reducing the cost of providing services, and the rate of interest to credit worthy customers, will be fair samples in the banking system.

\section{Conclusion and Presentation of Policy Recommendation}

Designing the Economic System, economic instruments, and economic mechanisms must be based on fairness to achieve the desired performance. In the present study, the effects and functions of fairness were determined in the Economic System. In the legal dimension of the Economic System, fairness can play a major role in resolving economic legal disputes. Flexibility and freedom of action in ruling, introducing ethical standards in decision making and notification of a sentence, distribute and redistribute fairly, and providing legal infrastructure for fair information flow are some functions of fairness in the legal dimension of the Economic System. 
In the field of international trade and international economics, fairness functions are in the two dimensions of preferential tariffs in favor of poor countries and the resolving foreign investment disputes. Transactions and trading are also other areas that are affected by fairness. Giving discount to the buyer, granting a debt repayment deadline, ignoring the debtor's essential property if there is a debt, and discount amount of damage or debt are some examples and functions of fairness in trading. Fairness in banking which is an important institution in the economies of the country, can also play a major role. Avoiding discrimination, fairness in determining the rate of facilities, establishment of the balanced development of wealth and assets in society, a fair treatment for claims management, and culture-building based on fairness In line with the fulfillment of obligations, are the most important application of fairness in the banking system.

Finally, some of the policy suggestions and recommendations are presented based on research findings as the following:

A) Policy suggestions related to economic institutions:

1) Provision of executive regulations and instructions in order to institutionalize fairness in activities;

2) Applying appropriate incentive tools to promote fairness in economic institutions;

3) Considering the fairness index as a criterion to assess the efficiency of economic institutions.

B) Policy suggestions related to international relations in the economy:

1) Introducing the international bodies such as the World Bank, International Monetary Fund, and the United Nations in economic relations between countries to achieve fairness

2) The attention of international courts to the fairness in issued sentences for the countries of the world

3) Considering the incentive facilities provided by international monetary institutions for fair trading.

C) Policy suggestions related to economic behavior:

1) Use of advertising and media instruments to institutionalize culture and the value of fairness in society

2) The use of behavioral instruments and nudge units in order to push society towards fairness in trading 


\section{References}

Ahangari, Behzad (2014). The fairness position in resolving disputes arising from foreign investment between governments and foreign investors, Master's thesis in Private Law, Shahid Chamran Ahwaz University

Amani Pour, Mona (2010). Fairness in Quran and Hadith, Master 'thesis on Qur'anic sciences, and hadith, Tehran: Tarbiat Modares University.

Asghari, Mohammad (2009). Justice as a rule. Tehran: Information Publishing.

Blaszczak, Lukasz, Kolber, Joanna (2013). General Principles of Law and Equity as a Basis for Decision-Making in Arbitration", Comparative Law Review.

Cooke, Chris (2009). What is the Difference between Justice and Fairness? Which is More Important? Unpublished.

Eivaz Lu, Hossein (2006). The introduction of the main pillars and core of Islamic economics, Sadeq Quarterly Journal, No. 3, pp. 123-156.

Falcon Y Tella, Maria Jose (2008). Equity and Law ,Translated into English by Peter Muckley, Leiden, Boston, Martinus Nihoff.

Herboczková, J(2008) .Amiable Composition in the International Commercial Arbitration", at : www.law.muni.cz

Hudson, Alastair (2015). Equity and Trusts ,"Eighth ed, London and New York, Routledge.

Mirmoezi, Seyed Hossein (2015). The macroeconomic structure of the Islamic Economic System: Tehran: Publication of the Culture and Arts Research Center.

Mohagheghnia, Mohammad Javad (2016). Introduction of Islamic Banking Indicators: Tehran: Publications of Imam Khomeini Educational and Research Institute.

Mousavian, Seyed Abbas; Meysami, Hussein (2016). Islamic Banking (1): Theoretical FoundationsPractical Experiences: Tehran: Publications of the Monetary and Banking Research Center.

Oxford Commentaries on International Law(2015). The UNCITRAL Arbitration Rules,"Caron, David, Caplan, Lee, Second Edition, New York, Oxford University Press.

Rabbani Mousavian, Seyed Ali; Naeemi, Tahere Sadat (2018). Examining the distinction between fairness and justice, and its application in Imamieh and Hanafi jurisprudence, Quarterly Journal of the Comparative Studies of Jurisprudence Religions, Second year, No. 3, and pp. 31-49.

Rawls, J. (1958). Justice as Fairness, The Philosophical Review, v. 67, N. 2, p. 164-194. Available at: http://www. jaredwoodard. com/ wp-content/ uploads/ rawls. pdf.

Rawls, John(1971) .A theory of Justice, Massachusetts: The Belknap Press of Harvard University Press.

Sekhon, H. S., Roy, S. K., \& Devlin, J. (April 04, 2016). Perceptions of fairness in financial services: an analysis of distribution channels. International Journal of Bank Marketing, 34, 2, 171-190.

Sheppard, Steve (2009). Equity and the law ,"in: Encyclopedia of Life Support Systems, Oxford, United Kingdom, Eolss Publishers UNESCO.

Stiglitz, J. E., \& Charlton, A. (2007). Fair trade for All: How trade can promote development. Oxford: Oxford University Press.

Tavakoli, Javad (2016). The concept of fairness in Islamic commercial ethics, Quarterly Journal of Ethics, Vol. 6, No. 1, pp. 25-46. 
Taylor, L. (2015). Social fairness and economics: Economic essays in the spirit of Duncan Foley. London: Routledge.

Villa, J. (2015). Ethics in banking: The role of moral values and judgements in finance. Palgrave Macmillan studies in banking and financial institutions. 